\title{
Handgrip and functional mobility in elderly with different levels of physical activity
}

Preensão palmar e mobilidade funcional em idosos com diferentes níveis de atividade física

Prensión palmar y la movilidad funcional en ancianos con diferentes niveles de actividad física

Dayane de Oliveira Macedo', Letícia Mendes de Freitas', Marcos Eduardo Scheicher ${ }^{2,3}$

\begin{abstract}
I The proportion of elderly people is growing worldwide and, with this, there is an increase of chronicdegenerative conditions such as impaired balance and falls. The physically active elderly tends to an improved response in muscle strength, flexibility and postural balance. The present study aimed to evaluate and compare the grip strength and mobility of elderly people with different levels of physical activity. The sample consisted of 44 elderly with 60 years or more, both sexes, divided in: 18 elderly practicing volleyball adapted (AVG), 13 elderly practicing some physical activity (AG) and 13 sedentary elderly (SG). Grip strength was assessed by a hydraulic dynamometer and mobility through the test "Timed Up and Go" (TUG). Data were evaluated using the KolmogorovSmirnov test, to check normality. The comparison of the results of the three groups was performed by ANOVA with Tukey post-test, with $\mathrm{p} \leq 0.05$. The results showed that grip strength ( $p=0.008)$ and mobility ( $p=0.003)$ were better to AVG when compared to the other groups. It is suggested that the sports practice implement the gains in functional mobility and strength when compared to purely non-specific exercise and inactivity.
\end{abstract}

Keywords I Muscle Strength; Motor Activity; Aging

RESUMO I A proporção de idosos está crescendo mundialmente e, com isso, observa-se aumento das condições crônico-degenerativas, como a diminuição do equilíbrio e as quedas. O idoso ativo fisicamente tende a apresentar uma melhora da resposta na força muscular, na flexibilidade e no equilíbrio postural. O presente estudo teve como objetivo avaliar e comparar a força de preensão palmar e a mobilidade de idosos com diferentes níveis de atividade física. A amostra foi composta por 44 idosos, com 60 anos e mais, de ambos os sexos, divididos em: 18 idosos praticantes de vôlei adaptado para a terceira idade (GVA), 13 idosos ativos (GA) praticantes de alguma atividade física e 13 idosos sedentários (GS). A força de preensão foi avaliada por um dinamômetro hidráulico e a mobilidade por meio do teste "Timed Up and Go" (TUG). Os dados foram avaliados pelo teste de Kolmogorov-Smirnov, para verificação da normalidade. Os dados foram comparados usando o teste ANOVA com pós-teste de Tukey, com ps0,05 como significante. Os resultados mostraram que a força de preensão ( $p=0,008)$ e a mobilidade $(p=0,003)$ foram melhores para o GVA, quando comparado aos outros grupos. Sugere-se que a prática esportiva implementaria os ganhos na mobilidade funcional e na força, quando comparada puramente a exercício físico não específico e ao sedentarismo.

Descritores | Força Muscular; Atividade Motora;

Envelhecimento.

RESUMEN I La proporción de ancianos está aumentando en todo el mundo, y con ello, se produjo un aumento de las enfermedades degenerativas crónicas, como trastornos del equilibrio y las caídas. El anciano físicamente activo tiende a mostrar una mejora de la respuesta en la fuerza muscular, en la flexibilidad y el equilibrio postural. El presente estudio tuvo como objetivo evaluar y comparar la fuerza de prensión palmar y la movilidad de mayores con diferentes niveles de actividad física. La muestra fue constituida por 44 adultos mayores de 60 años y más, de ambos

'School of Physical Therapy of the Universidade Estadual Paulista “Júlio de Mesquita Filho" (UNESP) - Marilia (SP), Brazil.

2Department of Physical and Occupational Therapy of the UNESP - Marilia (SP), Brazil.

${ }^{3}$ Program of Human and Technology Development of the Biosciences Institute of the UNESP - Rio Claro (SP), Brazil. 
sexos, divididos en: 18 mayores practicantes de voleibol adaptado para las personas mayores (GVA), 13 ancianos activos (GA) practicantes de alguna actividad física y 13 ancianos sedentarios (GS) La fuerza de prensión fue evaluada mediante un dinamómetro hidráulico y la movilidad por medio del exáman "Timed Up and Go" (TUG). Los datos fueron evaluados mediante el exámen de Kolmogorov-Smirnov, para comprobar la normalidad. Los datos fueron comparados utilizando el exámen ANOVA con pos exámen
Tukey, con ps0,05 como significante. Los resultados mostraron que la fuerza de prensión ( $p=0,008)$ y la movilidad $(p=0,003)$ fueron mejores para el GVA en comparación con los otros grupos. Se sugiere que la práctica de deportes implementaría las mejoras en la movilidad y la fuerza,cuando comparada únicamente al ejercicio física no específico y al sedentarismo.

Palabras clave I Fuerza Muscular; Actividad Motora; Envejecimiento

\section{INTRODUCTION}

According to demographic projections, 33 million Brazilians will be more than 60 years old in $2025^{1}$. Changes in postural balance and falls are among the most common changes related to human aging, and falls can cause considerable morbidity and mortality, affecting quality of life of this population ${ }^{2}$.

The deficit in muscle function, range of motion and decreased proprioceptive and sensory responses (visual, vestibular and somatosensory systems) is a common alteration with aging; in turn, this deficiency interferes with the individual's balance, predisposing them to a functional limitation and a higher risk of falls ${ }^{3-5}$.

Even the elderly presenting no changes in the performance of daily living activities (DLAs), the advancing age is associated with decreased mobility and muscle strength ${ }^{4}$. In this context, the measurement of the handgrip strength is suggested by the literature as a simple clinical measure in the tracking and identification of small functional changes, due to its association with the muscle function of the lower limbs. However, before adopting this practice, it is necessary that further studies are conducted in order to confirm this ${ }^{6}$. It is also known that the decrease in functional mobility is related to DLA and the predisposition to falls ${ }^{7}$.

On the other hand, the practice of physical exercises on a regular basis by the elderly have been targeted by the World Health Organization (WHO) ${ }^{8}$, and it may play an important role in reducing the losses inherent to aging ${ }^{9}$. There is strong evidence of the positive effects of exercise training on physical fitness, functional mobility, DLA performance and quality of life $\mathrm{e}^{10,11}$.

However, in the literature there are few studies which evaluated variables such as muscle strength and mobility in older adults with regular practice of guided physical activity, such as adapted volleyball, for example.
This sport has been part of many Seniors competitions, even having their own rules for its development.

Thus, this study aimed to evaluate and compare the functional mobility and handgrip strength of older people with different levels of physical activity.

\section{METHODOLOGY}

The project was approved by the Research Ethics Committee (CEP) of the School of Philosophy and Sciences (FFC), of the UNESP, Marília (SP) (Protocol No. 0426/2012), respecting the ethical recommendations of Resolution No. 196/96. All participants involved were informed about the research procedures and signed an Informed Consent.

\section{Sample}

The study included 44 elderly aged above 60 years of age, of both genders, divided into 3 groups: 18 elderly practitioners of senior-adapted volleyball (AVG), 13 physically active elderly $(\mathrm{AG})$ practicing any physical activity unrelated to sports, and 13 sedentary elderly (SG).

The participants on the AVG group were from the Society of Volleyball and Recreation for the Better Age (Grêmio de Vôlei e Recreação da Melhor Idade GREVERMI). They would perform the activity three times a week, with duration of an hour and a half, driven by a physical educator. The AVG aims at a sports practice for older people with changes in the rules of conventional volleyball in order to obtain a lower risk of injury. In this modality, the participant does not perform jumps during the pass, they retain the ball at the time of touch with both hands instead, they can hold four to five touches, instead of three, and the pass can be made with both hands and lateral deviation the body. 
Individuals in the $A G$ group were considered to be physically active when the exercise practice would occur, at least, 3 times a week, lasting at least 30 minutes, following the parameters of the Brazilian Society of Sports Medicine ${ }^{12}$. The sedentary elderly, despite being physically inactive, were independent to perform their DLAs. All participants were residents of the city of Marília (SP), Brazil.

The composition of the sample had as an exclusion criterion: sequelae of neuromusculoskeletal diseases, limiting arthritis for the performance of the required functions, uncorrected visual problems and postural hypotension. Seniors making continuous use of antidepressants, sedatives and hypnotics were also not included in the survey. In the cognitive evaluation, conducted by the Mini Mental State Examination (MMSE), the participants who achieved a score according to their level of education were accepted. The inclusion criteria were: 60 years of age or older, to be physically active or sedentary and to satisfy the conditions of the exclusion criteria.

\section{Instruments and procedures}

Participants underwent an initial assessment with a semistructured questionnaire, for the collection of personal data, existing illnesses, medications taken, level of physical activity and the occurrence of falls in the last year. In addition to that, all patients underwent the MMSE for cognitive screening ${ }^{13}$. Before and after the evaluation procedures, their vital signs such as blood pressure, respiratory rate and heart rate were taken. Participants were instructed not to perform any strenuous physical activity before data collection.

Grip strength was measured through a hydraulic dynamometer by North Coast ${ }^{\circledR}$, with adjustable levers and a manometer attached to the upper end. The test was performed with the participant sitting down in a specific given chair, shoulders adducted, elbow flexed to $90^{\circ}$, wrist in neutral position and slightly extended. Participants should exert maximum force, applying pressure on the lever against the base of the dynamometer, until its indicator arrow reached a peak. They were instructed through verbal stimuli as for the timing of the strength move performing, during an exhalation and without the Valsalva maneuver. The measurements of strength occurred three times, at intervals of at least one minute between them, alternating between the dominant and non-dominant side, always considering the greatest value ${ }^{14}$.
The assessment of functional mobility occurred through the test "Timed Up and Go" (TUG) ${ }^{15}$. This test assesses the level of mobility of the individual, measuring, in seconds, the time spent by the volunteer to stand up from a chair, without the help of their arms, walk three meters, turn around and return. At the beginning of the test, the volunteer should be with his back against the backrest and, at the end, they must lean back again. The volunteer received the "Go" instruction to perform the test, the time was recorded from the voice command until the moment that the voluntary leaned back on the chair again ${ }^{16}$.

\section{Statistical analysis}

The anthropometric data were presented as mean \pm standard deviation. The data were evaluated using the Kolmogorov-Smirnov test, in order to check normality. The comparison of the data between groups was performed using the ANOVA with the Tukey post-test, adopting $\mathrm{p} \leq 0.05$ as significant.

\section{RESULTS}

The characteristics of the participants as to the number, age and MMSE may be seen in Table 1.

Figure 1 shows the average handgrip strength for all three groups. The AVG group averaged (30.11 $\pm 11.69 \mathrm{kgf})$ higher than the AG $(21.23 \pm 8.18 \mathrm{kgf})$ and SG groups (20.30 $\pm 6.15 \mathrm{kgf})$. The intergroup analysis showed statistical significance between the AVG and the AG $(p=0.02)$ and between the AVG and the SG $(p=0.01)$. There was no significant difference between the AG and the SG ( $p=0.74)$ groups. Average values of functional mobility, assessed by the TUG test, are shown in Figure 2. The AVG participants performed the test at an average time of $(8.06 \pm 1.01 \mathrm{~s})$, significantly lower than the SG group ( $\mathrm{p}=0.003$ ) mean time. There was no statistical significance in comparison to the other groups (AVGxAG; AGxSG).

Table 1. Characteristics of the sample

$\begin{array}{lccc}\text { Variables } & \text { AVG } & \text { AG } & \text { SG } \\ n(M / F) & 18(9 / 9) & 13(5 / 8) & 13(4 / 9) \\ \text { Age (years) } \pm S D & 70.5 \pm 5.9 & 68.4 \pm 4.2 & 68.0 \pm 6.2 \\ \text { MMSE } \pm S D & 25.0 \pm 2.1 & 27.3 \pm 2.3 & 25.9 \pm 2.2\end{array}$

M: male; F: female; SD: standard-deviation; MMSE: Mini Mental State Exam; AVG: adapted volleyball group; AG: physically active group; SG: sedentary group 


\section{DISCUSSION}

The present study aimed to evaluate and compare the handgrip strength and functional mobility of older people with different levels of physical activity.

The results showed a better performance of the practitioners of AVG in both handgrip strength and mobility, when compared to the members of other groups (Figure 1 and Figure 2). One possible explanation for the results found would be that the volleyball group practices activities in a more directed way, with higher levels of physical activity, minimizing the declines of aging, as well as muscle strength, balance and mobility, suggesting that older adults who practice this activity have less inclination to falls ${ }^{17}$.

The handgrip strength showed that the AVG showed greater strength than the other groups. It should be noted that the AVG group had more men than the AG and the $S G$ ones and that, although the handgrip strength is identified as a predictor of functional disability, the results must be analyzed with caution, because the difference in the number of men may have affected the results. Furthermore, there is still disagreement on the literary

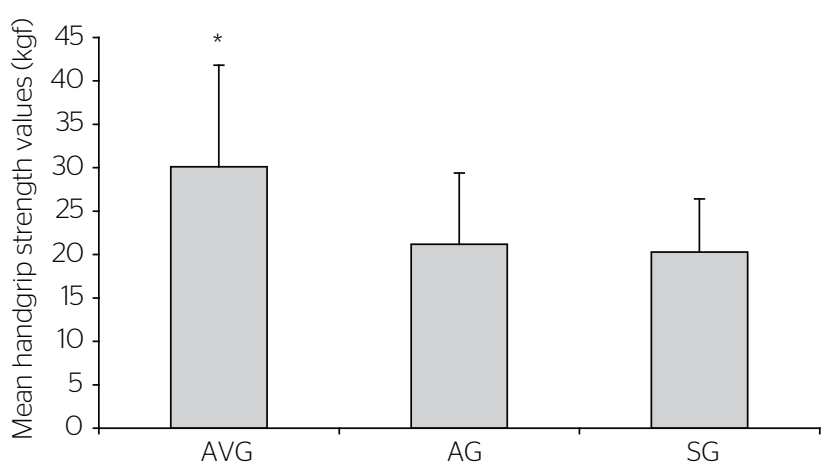

Figure 1. Mean handgrip strength

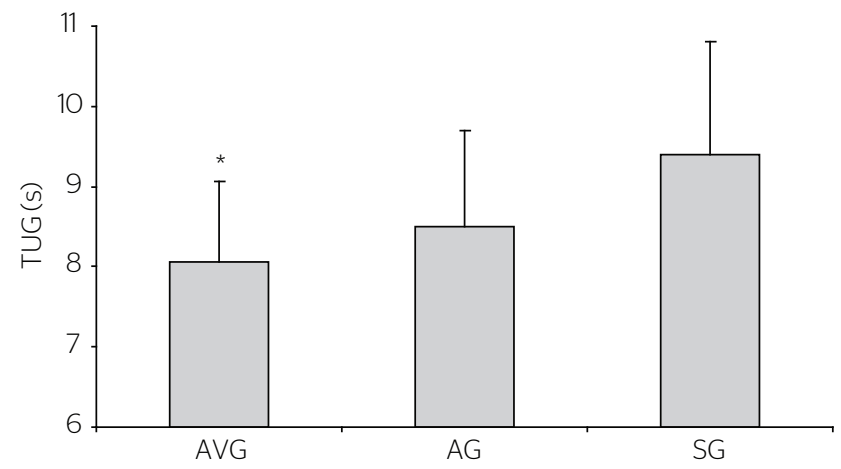

Figure 2. Mean Timed Up and Go values, in seconds adapted volleyball group (AVG, $n=18$ ); physically active group ( $A G, n=13$ ) and sedentary group (SG, $n=13$ ); ${ }^{*} \mathrm{p}=0,003$ related to $\mathrm{SG}$ use of this instrument as a meter marker of overall muscle strength ${ }^{18,19}$.

In the analysis of functional mobility, the comparison between the three groups showed significant difference between the AVG and the SG, despite the average values for the testing being lower than 10 seconds for all groups, time length considered great for lower rates of falls ${ }^{20}$. In the time variable, the AVG also showed better results than the other groups, which may be explained by the type of physical activity performed, because the exercises would challenge the balance, having a greater effect on mobility and on the prevention of falls than a simple walk and muscle strengthening alone ${ }^{21}$. Karlsson et al. ${ }^{22}$ indicate that both supervised unsupervised (home) exercises bring reduction in the number of falls, since they have more than two training components. The literature indicates that practicing physical or sports activities, them being oriented or not, brings benefits to the elderly population, for it decreases postural oscilations, improving balance and the proprioceptive responses ${ }^{23-25}$, predisposing them to a lower risk of falls, improved functionality and quality life $\mathrm{e}^{26}$.

Sherrington et al. ${ }^{27}$ described exercise recommendations to balance targeted exercises for the prevention of falls based on a meta-analysis. The authors reported that the exercises should challenge the balance in three different ways: changing the size of the base, the center of gravity and decreasing the use of upper limbs. However, for this practice to have results, there must be an established duration of at least two hours per week.

It is important to note, in this study, that both the AVG and the AG had satisfactory performance in the functional mobility test, with a predominance of the volleyball group. One possible explanation for this difference is that the AVG practiced activities that, in general, are more challenging to balance when compared to the group of seniors who performed physical activities without any guidance or the sedentary ones. In this sense, the adoption of public policies aimed at deploying senioradapted volleyball would bring benefits to this population regarding the decrease of the risk of falls.

\section{CONCLUSIONS}

In general, the results suggest that elderly who maintain a sports practice, adapted volleyball in this case, have better functional mobility and handgrip strength in relation to the other groups evaluated. 


\section{REFERENCES}

1. World Health Organization. Health of the elderly [Internet]. Technical Report Series, 779. Geneva: World Health Organization; 1989. [Citado em 20 maio 2013]. Disponível em: <http://whqlibdoc.who.int/trs/ WHO_TRS_779.pdf>

2. Bekibele CO, Gureje O. Fall incidence in a population of elderly persons in Nigeria. Gerontology. 2010;56(3):278-83.

3. Carvalho J, Oliveira J, Magalhães J, Ascensão A, Mota J, Soares JMC. Força muscular em idosos II - Efeitos de um programa complementar de treino na força muscular de idosos de ambos os sexos. Rev Port Cien Desp. 2004;4(1):58-65.

4. Lacourt MX, Marini LL. Decréscimo da função muscular decorrente do envelhecimento e a influência na qualidade de vida do idoso: uma revisão de literatura. Revista Brasileira de Ciência do Envelhecimento Humano. 2006;3(1):114-21.

5. Horak FB. Postural orientation and equilibrium: what do we need to know about neural control of balance to prevent falls? Age Ageing 2006:35(Supl. 2):7-11.

6. Garcia PA, Dias JMD, Dias RC, Santos P, Zampa CC. Estudo da relação entre função muscular, mobilidade funcional e nível de atividade física em idosos comunitários. Ver Bras Ffisioter. 2011;15(1):15-22.

7. Alfieri FM, Teodori RM, Montebelo MIL. Mobilidade funcional de idosos submetidos a intervenção fisioterapêutica. Saúde Rev. 2004;6(14):45-50.

8. Organização Mundial de Saúde. Aging [Internet]. [Citado em 08 jul 2013]. Disponível em: <http://www.who.int/topics/ageing/en/>

9. Seco J, Abecia LC, Echevarría E, Barbero I, Torres-Unda J, Rodriguez $\checkmark$, et al. A long-term physical activity training program increases strength and flexibility, and improves balance in older adults. Rehabil Nurs. 2013;38(1):37-47.

10. Weening-Dijksterhuis E, de Greef MH, Scherder EJ, Slaets JP, van der Schans CP. Frail institutionalized older persons: A comprehensive review on physical exercise, physical fitness, activities of daily living, and quality-of-life. Am J Phys Med Rehabil. 2011;90(2):156-68.

11. Intiso D, Di Rienzo F, Russo M, Pazienza L, Tolfa M, larossi A, et al. Rehabilitation strategy in the elderly. J Nephrol. 2012;25(Suppl. 19):90-5.

12. Leitão MB, Lazzoli JK, Oliveira MAB, Nóbrega ACL, Silveira GG, Carvalho T, et al. Posição oficial da Sociedade Brasileira de Medicina do Esporte: atividade física e saúde. Rev Bras Med Esporte. 1996:4:79-81.

13. Brucki SMD, Nitrini R, Caramelli P, Bertolucci PHF, Okamoto $\mathbb{H}$. Sugestões para o uso do Mini-Exame do Estado Mental no Brasil. Arq Neuro-psiquiatr. 2003;61(3B):777-81.
14. Figueiredo IM, Sampaio RF, Mancini MC, Silva FCM, Souza MAP. Teste da força de preensão utilizando o dinamômetro Jamar. Acta Fisiatr. 2007:14(2):104-10.

15. Mancini M, Horak FB. The relevance of clinical balance assessment tools of differentiate balance deficits. Eur J Phys Rehabil Med. 2010:46(2):239-48.

16. Podsiadlo D, Richardson S. The Timed “Up \& GO": a test of basic functional mobility for frail elderly persons. J Am Geriatr Soc. 1991;39(2):142-8

17. Mazo GZ, Liposcki DB, Ananda C, Prevê D. Condições de saúde, incidência de quedas e nível de atividade física dos idosos. Rev Bras Fisioter. 2007;11(6):437-42.

18. den Ouden MEM, Schuurmans MJ, Arts IE, van der Schouw YT. Physical performance characteristics related to disability in older persons: A systematic review. Maturitas. 2011;69(3):208-19.

19. Geraldes AR, Oliveira ARM, Albuquerque RBD, Carvalho JM, Farinatti PTV. A força de preensão manual é boa preditora do desempenho funcional de idosos frágeis: um estudo correlacional múltiplo. Rev Bras Med Esporte. 2008;14(1):12-6.

20. Bohannon RW. Reference values for the timed up and go test: a descriptive meta-analysis. J Geriatr Phys Ther. 2006;29(2):64-8.

21. Sherrington C, Lord SR, Close JCT.. Best-practice recommendations for physical activity to prevent falls in older adults [Internet]. [Citado em 15 maio 2013]. Disponível em: <http://fallsnetwork.powmri.edu.au/ resources/files/aaa-sax-pa-falls.pdf>

22. Karlsson MK, Vonschewelov T, Karlsson C, Cöster M, Rosengen BE. Prevention of falls in the elderly: a review. Scand J Public Health. 2013;41(5):442-54

23. Kiers H, van Dieën J, Dekkers H, Wittink H, Vanhees L. A systematic review of the relationship between physical activities in sports or daily life and postural sway in upright stance. Sports Med. 2013;43(11):1171-89.

24. Gauchard GC, Jeandel C, Perrin PP. Physical and sporting activities improve vestibular afferent usage and balance in elderly human subjects. Gerontology. 2001;47(5):263-70.

25. Perrin PP, Gauchard GC, Perrot C, Jeandel C. Effects of physical and sporting activities on balance control in elderly people. Br J Sports Med.1999;33(2):121-6.

26. Skelton DA. Effects of physical activity on postural stability. Age Ageing. 2001;30(Suppl. 4):33-9.

27. Sherrington C, Tiedemann A, Fairhall N, Close JCT, Lord SR. Exercise to prevent falls in older adults: an updated meta-analysis and best practice recommendations. N S W Public Health Bull. 2011;22(3-4):78-83. 